\title{
IMA Genome-F 11
}

\section{Draft genome sequences of Fusarium xylarioides, Teratosphaeria gauchensis and T. zuluensis and genome annotation for Ceratocystis fimbriata}

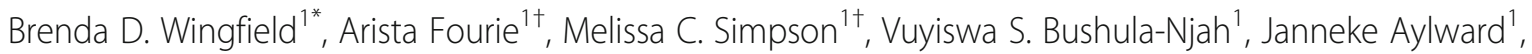 \\ Irene Barnes ${ }^{1}$, Martin P. A. Coetzee ${ }^{1}$, Léanne L. Dreyer², Tuan A. Duong ${ }^{1}$, David M. Geiser ${ }^{3}$, Francois Roets ${ }^{4}$, \\ E. T. Steenkamp ${ }^{1}$, Magriet A. van der Nest ${ }^{1,6}$, Carel J. van Heerden ${ }^{5}$ and Michael J. Wingfield ${ }^{1}$
}

\begin{abstract}
Draft genomes of the fungal species Fusarium xylarioides, Teratosphaeria gauchensis and T. zuluensis are presented. In addition an annotation of the genome of Ceratocystis fimbriata is presented. Overall these genomes provide a valuable resource for understanding the molecular processes underlying pathogenicity and potential management strategies of these economically important fungi.
\end{abstract}

Keywords: Genome announcement, Genome annotation, Fungal pathogen, Coffee pathogen, Eucalyptus canker pathogen, Fusarium xylarioides, Teratosphaeria gauchensis, T. zuluensis

\section{IMA GENOME-F 11A}

Genome annotation for Ceratocystis fimbriata: an aggressive fungal pathogen of root crops

\section{Introduction}

The genus Ceratocystis includes 41 species of mainly plant pathogenic fungi (Marin-Felix et al. 2017; Holland et al. 2019 Barnes et al. 2018; Liu et al. 2018). The type species, Ceratocystis fimbriata, was first described in the USA in 1890 as the causal agent of black rot of Ipomoea batatas (Halsted 1890). It shows strong host specificity and does not infect tree hosts, in contrast to many other species in this genus (Baker et al. 2003; Fourie et al. 2018). The pathogen is known in various parts of the USA as well as in Asian countries including Papua New Guinea, China, Japan, Hawaii and New Zealand (Halsted and Fairchild 1891; Lewthwaite et al. 2011; Li et al. 2016). Population genetic analyses of isolates collected in these countries have revealed a very low genetic diversity in all the populations

\footnotetext{
* Correspondence: Brenda.Wingfield@fabi.up.ac.za

${ }^{+}$Arista Fourie and Melissa C. Simpson contributed equally to this work.

${ }^{1}$ Department of Biochemistry, Genetics and Microbiology (BGM), Forestry and Agricultural Biotechnology Institute (FABI), University of Pretoria, Private Bag X20, Hatfield 0028, South Africa

Full list of author information is available at the end of the article
}

and $C$. fimbriata thus appears to be a near clonal species (Li et al. 2016; Scruggs et al. 2017).

The sexual fruiting structures in Ceratocystis spp., including C. fimbriata, are flask-shaped ascomata with long necks exuding sticky ascospore masses at their apices (Wingfield et al. 2017b). Ceratocystis fimbriata, along with all other species of Ceratocystis, is self-fertile (Halsted 1890; De Beer et al. 2014). The fungus includes isolates that are self-sterile, arising from a phenomenon known as unidirectional mating-type switching, where an isolate of the opposite mating-type is required for sexual reproduction to occur (Harrington and McNew 1997; Witthuhn et al. 2000; Wilken et al. 2014).

Genome sequences represent valuable scientific resources that provide an important source of information needed to understand the biology of organisms. A draft genome sequence of $C$. fimbriata (isolate CBS114723) was published in 2013 (Wilken et al. 2013) and these data were specifically used to characterise the matingtype locus of the isolate (Wilken et al. 2014). Genomes of other species of Ceratocystis, including C. albifundus (Van der Nest et al. 2014a), C. eucalypticola (Wingfield et al. 2015b) and C. manginecans (Van der Nest et al. 2014b), have also been published, and form part of a 
larger genome sequencing project. The aim of this study was firstly to improve the genome assembly of $C$. fimbriata, the type species of this genus, and secondly to provide a curated annotation of this genome that can serve as a resource for other species in the genus. Here, we present an improved assembly of $C$. fimbriata with significantly fewer contigs than the previous assembly, and the first annotation of this genome http://www.ncbi. nlm.nih.gov/Taxonomy/Browser/wwwtax.cgi?lvl=0\&id= 5158, with RNA data incorporated to improve gene prediction. Genomes of Ceratocystidaceae provide an opportunity to investigate various taxonomic and evolutionary questions of an important group of plant pathogens.

\section{Sequenced strains}

USA: North Carolina, isolated from Ipomoea batatas, Dec, 1998, D. McNew (CMW14799, C1421, CBS114723).

\section{Nucleotide sequence accession number}

The genomic sequence of Ceratocystis fimbriata (CMW14799, CBS114723) has been deposited at DDBJ/ EMBL/GenBank under accession no. APWK00000000. The version described in this paper is version APWK03000000. RNA sequencing data has been deposited in the NBCI Short Read Archive under accession number PRJNA67151.

\section{Materials and methods}

Ceratocystis fimbriata was grown on 2\% (w/v) MEA (Biolab, Merck, South Africa), supplemented with 150 $\mathrm{mg} / \mathrm{L}$ streptomycin and $100 \mu \mathrm{g} / \mathrm{L}$ thymine (MEA-ST medium), at room temperature $\left(22-24{ }^{\circ} \mathrm{C}\right)$ for two weeks. DNA extraction was performed using the protocol described by Goodwin et al. (1992) with minor modifications. An RNase treatment step was included after the first phenol/chloroform step and incubated for $1 \mathrm{~h}$ at $37^{\circ} \mathrm{C}$. The RNase was then removed with a subsequent phenol/chloroform step. DNA purity was determined using a ND_1000 Spectrophotometer (Nanodrop, Wilmington, $\mathrm{DE})$. The integrity of the genomic DNA was determined with agarose gel electrophoresis on a $1 \%$ gel. DNA quantity was determined with a Qubit ${ }^{\circ}$ 2.0 Fluorometer (ThermoFisher Scientific, Waltham, USA) following the manufacturer's protocol.

To verify the identity of the isolate and the absence of bacterial contamination, the fungal ITS regions 1 and 2, including the $5.8 \mathrm{~S}$ rRNA gene (refered collectively as the ITS region) of the ribosomal operon and a portion of the bacterial 16S rRNA were amplified. Amplification and amplicon purification of the ITS region were performed, as described by Fourie et al. (2015), using primers ITS1 and ITS4 (White et al. 1990). The sequence of the PCR product was determined with Sanger sequencing using an ABI Big DYE Terminator Cycle Sequencing Ready Reaction Kit (Applied BioSystems, Thermo Fisher, California, USA). The ITS sequence was then aligned against that of $C$. fimbriata. The $16 \mathrm{~S}$ rRNA region was amplified using primers $27 \mathrm{~F}$ and 1492R (DeLong 1992) and PCR cycler conditions from Beukes et al. (2013), including a positive control bacterial DNA sample. The absence of a PCR band confirmed the absence of bacterial DNA in the sample.

The taxonomic placement of C. fimbriata among the Microascales was investigated by means of a phylogenetic analysis of three combined gene regions, the $28 \mathrm{~S}$ and 60S ribosomal RNA and the Mcm7 (DNA replication licensing factor) gene regions. The sequences of representative isolates of the different genera in this order were obtained from GenBank, as reported by De Beer et al. (2014), and aligned using Muscle alignment in MEGA v.7 (Kumar et al. 2016). A maximum likelihood analysis was performed with the sequence data, using RaxML v.8.2.11 (Stamatakis 2014), model parameters were estimated by the software and 1000 bootstrap replicates were performed to obtain branch support values. The Graphium genus was selected as outgroup.

Genome sequencing was performed by FASTERIS SA, Switzerland. All libraries were combined in one lane of an Illumina HiSeq 2500 instrument that produces reads of $125 \mathrm{bp}$ in length. Three libraries were constructed; consisting of a $3000 \mathrm{bp}$ insert mate-pair library and both a $300 \mathrm{bp}$ and $500 \mathrm{bp}$ paired-end library. Illumina adapter sequences were removed from the reads by FASTERIS. Initial quality control (QC) of the sequence reads of each library was performed using FastQC (Andrews 2010). Low quality reads (leading and trailing Phred score $<20$ ) and reads shorter than $20 \mathrm{bp}$ (mate-pair) and $100 \mathrm{bp}$ (paired-end), respectively, were removed from the data using Trimmomatic (Bolger et al. 2014). Analysis with FastQC was repeated, after read trimming, to ensure all reads had a Phred quality score above 20 and that all adapters were removed.

Genome assemblies were performed using Velvet Optimiser v.2.2.5 (Zerbino and Birney 2008) optimising for k-mer values between 61 and 99. Velvet Optimiser indicated a k-mer value of 99 to be optimal. All contigs below $500 \mathrm{bp}$ were discarded. The assembled contigs were subsequently joined into scaffolds by incorporating the mate-pair library data, using the program SSPACE v.2 (Boetzer et al. 2011). Parameters were set to extend contigs, using unmapped reads and five read pairs were required to support the joining of two contigs for the creation of scaffolds. Raw reads were mapped back to the genome to fill in gaps within scaffolds using the software GapFiller v.1.10 (Boetzer and Pirovano 2012). Standard parameters were retained except that a minimum overlap of $100 \mathrm{bp}$ was selected for reads mapped 
back to the scaffolds and read trimming was switched off. The pipeline BUSCO (Benchmarking Universal SingleCopy Orthologs; Simão et al. 2015) was used to determine the percentage of conserved Ascomycete (1315 genes) and Sordariomycete (3375 genes) single-copy orthologs present in the genome.

RNA extraction was performed on mycelial and ascomatal tissue harvested from three agar plates after ten days of growth. Liquid nitrogen was used to flash freeze the harvested tissue after which a mortar and pestle was used to grind it to a fine powder. RNA extractions were then performed using the $\mathrm{RNeasy}^{\circ}$ Plant Mini Kit (Qiagen, Limburg, The Netherlands) following the manufacturer's instructions but the RLC buffer was replaced with RLT buffer, and the optional DNase-1 digestion step was included. Quality of the extracted total RNA was evaluated using agarose gel electrophoresis with $2 \%(\mathrm{w} / \mathrm{v})$ agarose (Seakem). The concentration was then measured using a ND_1000 Spectrophotometer (Nanodrop, Wilmington, DE). Further quality assessment was performed using the Experion ${ }^{\mathrm{Tx}}$ automated electrophoresis system (Bio-Rad Laboratories, California, USA). The extracted RNA was enriched for mRNA using Dynabead ${ }^{\circ}$ mRNA purification kit (ThermoFisher Scientific, Waltham, USA) and then subjected to cDNA synthesis, library preparation and sequencing at the Central Analytical Facilities, Stellenbosch University, South Africa, using the Ion Proton Platform and $\mathrm{PI}^{\mathrm{m}}$ Chip system (Life Technologies, Carlsbad, CA). Quality of the raw reads was checked using FastQC as described above. Sequences were trimmed using Trimmomatic by removing low quality reads (leading and trailing Phred score $<20$ ), reads below $20 \mathrm{bp}$ in length, the first $20 \mathrm{bp}$ of each read (due to low quality), and any bases over $300 \mathrm{bp}$ in length.

The MAKER genome annotation pipeline v2.31.8 (Cantarel et al. 2008; Holt and Yandell 2011) was used for structural annotation of the genome. RNA-Seq data was incorporated into training of gene predictors and used as gene evidence during all MAKER iterations. The RNA-Seq reads were aligned to the genome with STAR (Dobin et al. 2013) and transcripts were assembled with Cufflinks (Trapnell et al. 2012). The aligned RNA-Seq reads in BAM format were incorporated into the Braker1 pipeline (Hoff et al. 2016) for training of AUGUSTUS v.3.2.1 (Stanke et al. 2004) and GeneMarkET (Lomsadze et al. 2014). SNAP (Korf 2004) was trained with transcripts assembled from Cufflinks using the est2genome function in MAKER. A species specific repeat library was created using RepeatScout (Price et al. 2005) and RepeatMasker (Smit et al. 1996-2010). This repeat library was used to mask the genome against repetitive elements before performing gene prediction in MAKER. A final MAKER run was conducted using trained parameters from SNAP, AUGUSTUS and GeneMark.
FgeneSH (Solovyev et al. 2006) was run based on parameters pre-optimised for Neurospora crassa and the gene models obtained were passed over to MAKER in the final run. Gene models obtained from MAKER were visualised using WebApollo (Lee et al. 2013), along with RNA-seq evidence aligned to the genome, and all gene models were examined and curated, where necessary, based on the RNA-Seq evidence.

Functional annotation of the genes was based on comparison to various databases. A BLASTp analysis was performed for all proteins against the Swissprot database. Proteins were also compared to the Protein family (Pfam) database using InterProScan v.5.24 (Jones et al. 2014). SignalP v.4.0 (Petersen et al. 2011) was used to predict secretion signals and Phobius v.1 (Käll et al. 2004) was used to predict the presence of transmembrane domains. To predict the number of genes present in internal clusters, the genes involved in secondary metabolite production were determined using the antiSMASH v.3 software available online (Weber et al. 2015). The functional annotations predicted for each protein were added to the gff file using the software ANNIE (Ooi et al. 2009) and GAG (Hall et al. 2014).

\section{Results and discussion}

The paired-end and mate-pair sequencing generated approximately 42,5 million raw reads with an average length of $166 \mathrm{bp}$. Trimmed reads were assembled into 399 scaffolds, ranging in size from $500 \mathrm{bp}$ to $516595 \mathrm{bp}$, with an average read coverage of 630 and N50 value of 173733 bp. The C. fimbriata genome was 3015998 bp in size with a GC content of $45.6 \%$. There were 7728 predicted genes, of which 7266 (94\%) were protein-coding genes, 105 (1.36\%) were rRNA genes and 348 (4.5\%) were tRNA genes. In total, $62 \%$ of the genes could be annotated with a known function. The $C$. fimbriata genome contained 98\% Ascomycete and 90\% Sordariomycete completed BUSCO gene models. The taxonomic placement of C. fimbriata among the Microascales is illustrated in Fig. 1. The sequence alignments were submitted to Treebase (24031).

This study showed that $C$. fimbriata has far fewer genes than other fungal plant pathogens with similar genome sizes. For example, the head blight pathogen Fusarium graminearum (genome size: $36.5 \mathrm{Mb}$ ) has approximately 14164 genes (King et al. 2015), the pine needle blight pathogen Dothistroma septosporum (genome size: 31.2 $\mathrm{Mb}$ ) has 12580 genes (De Wit et al. 2012) and the wilt pathogen Verticillium dahliae (genome size: $33.8 \mathrm{Mb}$ ) has 10535 genes (Klosterman et al. 2011). The number of genes in C. fimbriata does, however, correspond with those of other Ceratocystis species (Van der Nest et al. 2014a; Van der Nest et al. 2014b; Wingfield et al. 2015b; Wingfield et al. 2016b). There are currently eight genomes 


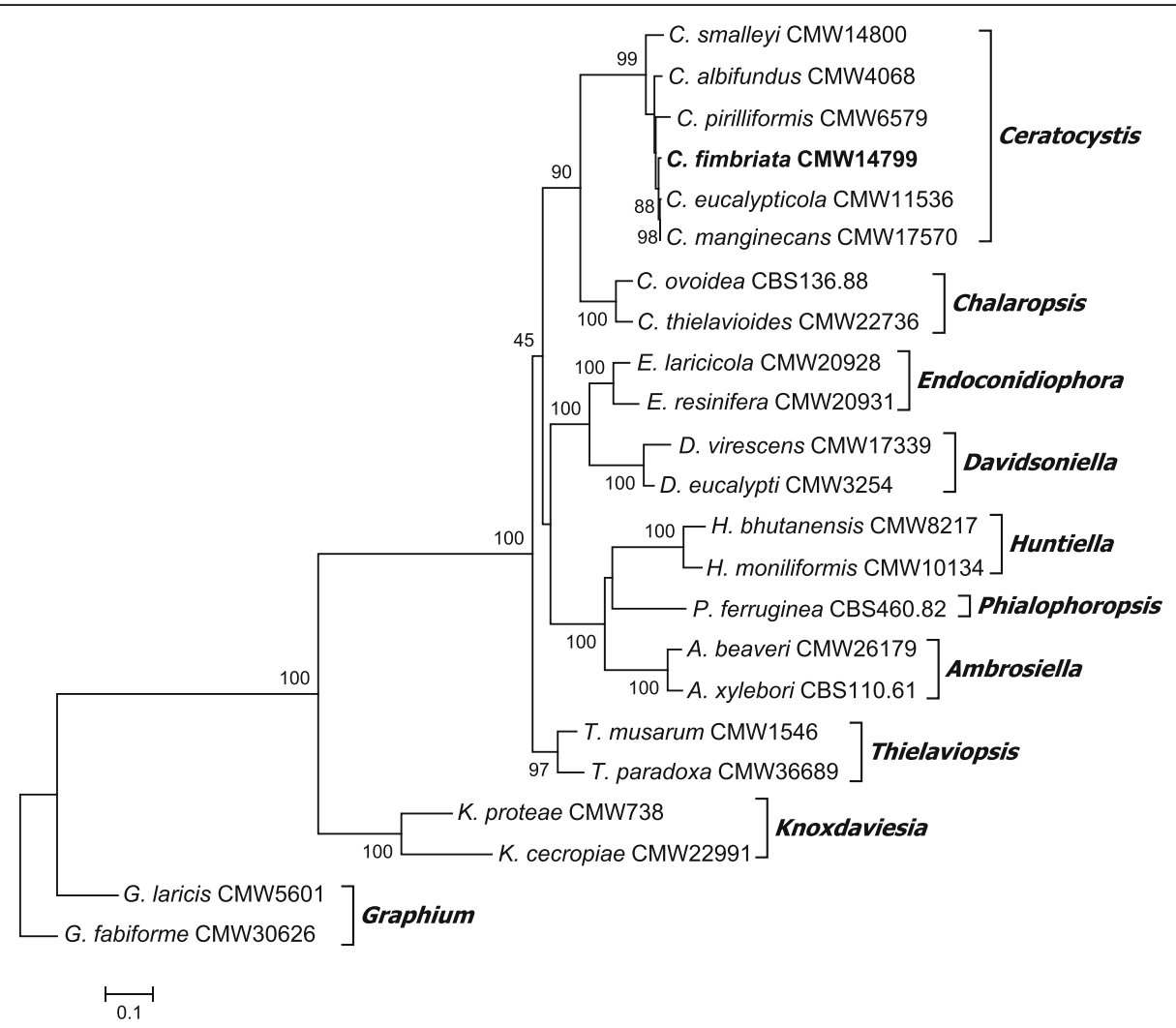

Fig. 1 Phylogenetic tree depicting the relationship between C. fimbriata (in bold) and related species and genera in the Microascales. The tree was constructed from 60S, LSU, MCM7 gene regions using RaxML. Bootstrap support (1000 replicates) are indicated at the nodes

publicly available for species of Ceratocystis and 18 in the Ceratocystidaceae (Wilken et al. 2013; Van der Nest et al. 2014a; Van der Nest et al. 2014b; Van der Nest et al. 2015; Wingfield et al. 2015a; Wingfield et al. 2015b; Wingfield et al. 2016a; Wingfield et al. 2017; Molano et al. 2018; Vanderpool et al. 2018; Wingfield et al. 2018a). The annotation of the $C$. fimbriata genome sequence presented in this study is the first manually curated genome including additional RNA evidence, for any species in the Ceratocystidaceae. This annotation will provide the means to improve annotations for other species of Ceratocystis and provides an improved assembly that can be used for future comparative studies.

Authors: A. Fourie*, M.C. Simpson*, T.A. Duong, I. Barnes, M.P.A. Coetzee, M.A. van der Nest, M.J. Wingfield and B.D. Wingfield.

*Contact: melissa.simpson@fabi.up.ac.za or arista.four ie@fabi.up.ac.za (authors contributed equally)

\section{IMA GENOME-F 11B}

\section{Draft genome sequence of Fusarium xylarioides} Introduction

Fusarium xylarioides Steyaert (1948) is a soilborne fungal pathogen that causes coffee wilt disease (CWD) in many coffee growing regions in Africa (Rutherford 2006). The sexual stage, previously referred to as Gibberella xylarioides (Heim 1950), is readily observed in CWD infested trees (Ploetz 2006). This heterothallic fungus is a member of the F. fujikuroi species complex (FFSC), a group of phylogenetic species that infect a number of important crops (O'Donnell et al. 1998; O'Donnell et al. 2000). Previous studies have reported the presence of two genetically and biologically distinct forms of this pathogen (Geiser et al. 2005; Lepoint et al. 2005), but their taxonomy has not yet been conclusively resolved. The availability of a complete genome sequence will, therefore, serve as the starting point for addressing the taxonomic confusion about this species in the literature. Also, more genetic data on this species will enable studies on its biology and evolution.

\section{Sequenced strain}

Uganda: Iganga District: Isolated from Coffea canephora, Dec. 2000, D.M. Geiser (KSU $18978=$ FRC L-0394= CMW 53787 - living culture).

\section{Nucleotide sequence accession number}

The whole genome shotgun sequencing project of Fusarium xylarioides KSU 18978 (FRC-L0394 = CMW 53787) has been deposited at DDBJ/ENA/GenBank under the 
accession no. SRZU00000000. The version described in this paper is version SRZU01000000.

\begin{abstract}
Materials and methods
Fusarium xylarioides KSU 18978 (CMW 53787) was obtained from the culture collection (CMW) of the Forestry and Agricultural Biotechnology Institute (FABI), University of Pretoria. The isolate was grown in $40 \mathrm{ml}$ potato dextrose broth ( $20 \%$ potato dextrose broth w/v) and incubated on an orbital shaker $(135 \mathrm{rpm})$ for $2 \mathrm{~d}$ at room temperature $\left(22-25^{\circ} \mathrm{C}\right)$. Genomic DNA was extracted following the method of Duong et al. (2013). One pair-end library of $250 \mathrm{bp}$ read length and $550 \mathrm{bp}$ insert size was prepared and sequenced using the Illumina HiSeq 2500 platform. Quality control of pair-end reads received and adapter trimming was performed in the program Trimmomatic v. 0.36 (Bolger et al. 2014). Genome assembly was performed from trimmed reads using SPAdes v. 3.10 (Bankevich et al. 2012) and further scaffolding was performed using SSPACE Standard v. 3.0 (Boetzer et al. 2011). The genome quality and completeness were evaluated with BUSCO v. 2.0 (Simão et al. 2015) using the dataset for Sordariomycetes. The number of protein-coding genes encoded by the genome was evaluated with the program AUGUSTUS v. 3.2.2 (Stanke et al. 2006) using Fusarium graminearum as a species model. The taxonomic identity of the sequenced genome was confirmed by Maximum likelihood (ML) analysis of authenticated sequences using MEGA version X (Kumar et al. 2018).
\end{abstract}

\section{Results and discussion}

The assembled draft genome of Fusarium xylarioides was estimated to be $55.24 \mathrm{Mb}$ with a coverage of $61 \mathrm{x}$, corresponding to 424 scaffolds larger than $500 \mathrm{bp}$ with an N50 value of $250204 \mathrm{bp}$, and an average GC content of $43.4 \%$. Among the FFSC species for which genomes sequences are available, F. xylarioides thus has the largest predicted genome size, i.e., the genomes of $F$. circinatum is $43.43 \mathrm{Mb}, F$. temperatum $45.46 \mathrm{Mb}, \quad F$. fracticaudum $46.29 \mathrm{Mb}$, F. pininemorale $47.83 \mathrm{Mb}$, and F. nygamai is $51.61 \mathrm{Mb}$ (Wingfield et al. 2015a, 2015b, 2017, 2018a). The predicted size of our sequenced genome was similar to that of another $F$. xylarioides strain

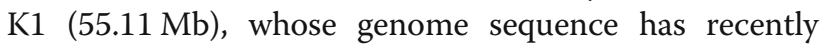
been made available on NCBI under nucleotide accession number GCA_004329255.

Based on BUSCO analysis, genome completeness was 99.0\% (C:3687 [S:3680, D:7], F:26, M:12, n:3725), suggesting that the assembly covers the majority of the organism's gene content. AUGUSTUS predicted that the assembly encodes 14588 open reading frames (ORFs) and this was in agreement with data from other members of the FFSC (Wingfield et al. 2015a, 2015b, 2017, 2018a).
Phylogenetic analysis based on partial gene sequences of $\beta$-tubulin and TEF- $1 \alpha$ confirmed the sequenced genome to be of F.xylarioides (Fig. 2). F. xylarioides and F. udum are the only two members of the FFSC that cause true vascular wilt diseases (Geiser et al. 2005). Therefore, the increase in available whole genome data will not only allow for taxonomic re-evaluation of $F$. xylarioides, but will also enable comparative genomics studies to better understand the biology and evolution of members of the FFSC.

Authors: V.S. Bushula-Njah*, T.A. Duong, D.M. Geiser, E.T. Steenkamp, and B.D. Wingfield.

"Contact: Vuyiswa.bushula@fabi.up.ac.za

\section{IMA GENOME-F 11C}

Draft genome sequences of Teratosphaeria gauchensis and $T$. zuluensis, causal agents of Teratosphaeria stem canker

Introduction

Teratosphaeria stem canker (previously known as Coniothyrium canker) is a fungal disease of Eucalyptus trees planted outside of their native range for the production of wood and non-wood products. Since its discovery in a South African plantation in the late 1980's (Wingfield et al. 1996), this disease has emerged in Eucalyptus plantations in 14 additional countries where tropical or subtropical climates predominate (Aylward et al. 2019). Infection is characterized by necrotic lesions that grow and eventually merge to form large gum-filled, bleeding cankers (Wingfield et al. 1996). Gum-stained wood is unsuitable for timber production and lesions hinder debarking so that pulping is affected (Old et al. 2003).

Teratosphaeria gauchensis and T. zuluensis, Dothideomycete fungi (Capnodiales, Teratosphaeriaceae), cause Teratosphaeria stem canker independently (Cortinas et al. 2006). These two species are unique in that they are the only known stem canker pathogens in a genus predominantly associated with the leaves of Eucalyptus species (Fig. 3; Quaedvlieg et al. 2014). Until recently, they were thought to have distinct geographic distributions, but in 2014 both were identified in a Ugandan plantation (Jimu et al. 2014). Together with the 2015 discovery of T. gauchensis in southern Africa (Jimu et al. 2015), this suggests that concurrent infections are bound to occur in plantations of central and southern Africa (Aylward et al. 2019).

We present the genome sequences of the ex-holotype of T. gauchensis (CBS 119465) and the ex-type of T. zuluensis (CBS 119470). These genomes will enable exploration of the intriguing case of two different species causing identical disease symptoms. Future studies will focus on the eucalypt stem specificity of these pathogens in contrast to the widespread eucalypt leaf association of other Teratosphaeria species. 


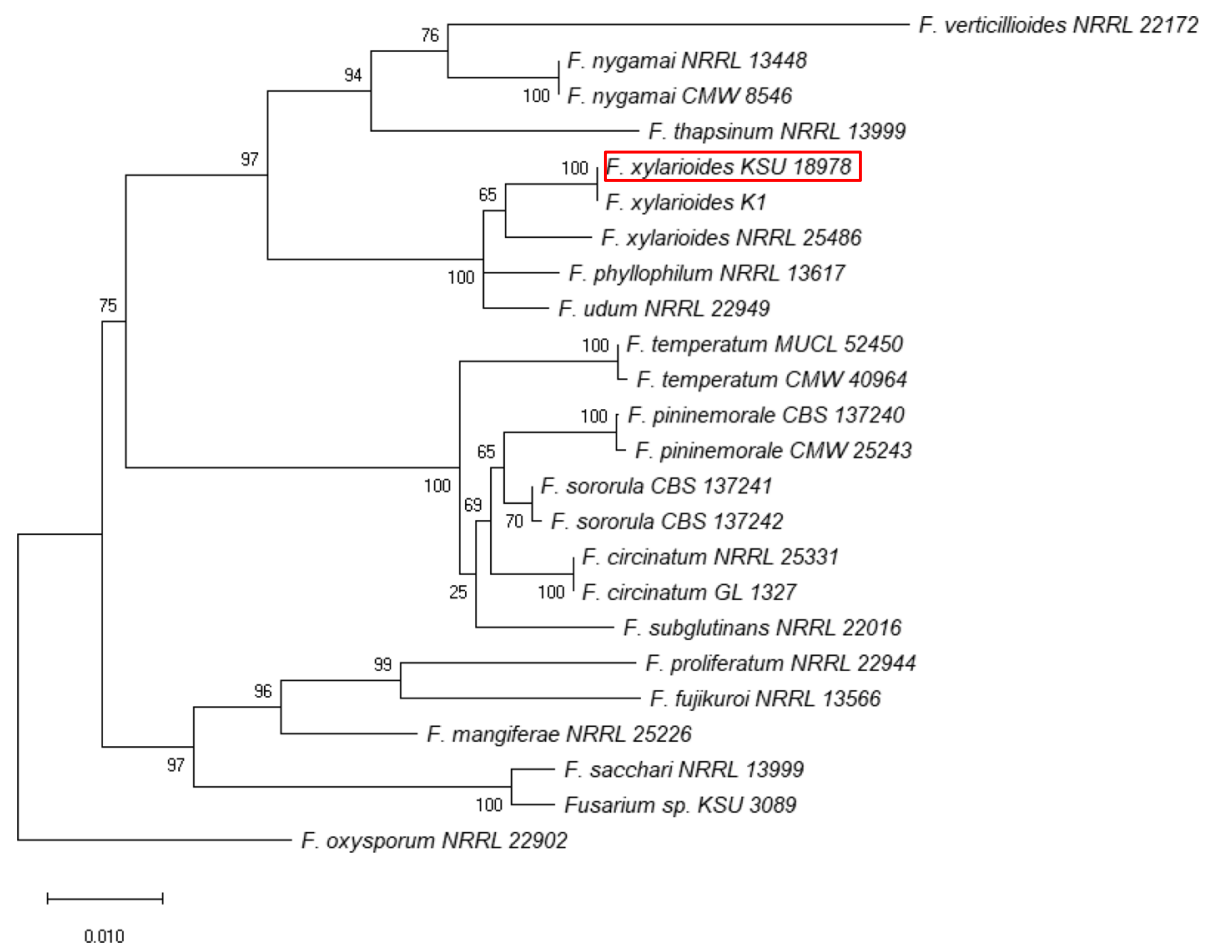

Fig. 2 Maximum likelihood (ML) tree based on partial gene sequences of $\beta$-tubulin and translation elongation factor 1-a. Sequence alignments were assembled with MAFFT version 7 (Katoh and Standley 2013). The program MEGA X version 7 (Kumar et al. 2018) was used to estimate the best-fit substitution model (TN93) with a discrete gamma distribution $(+G)$. The same program was used for ML phylogenetic analysis and percentage bootstrap support (1000 replications) values are indicated at branch nodes

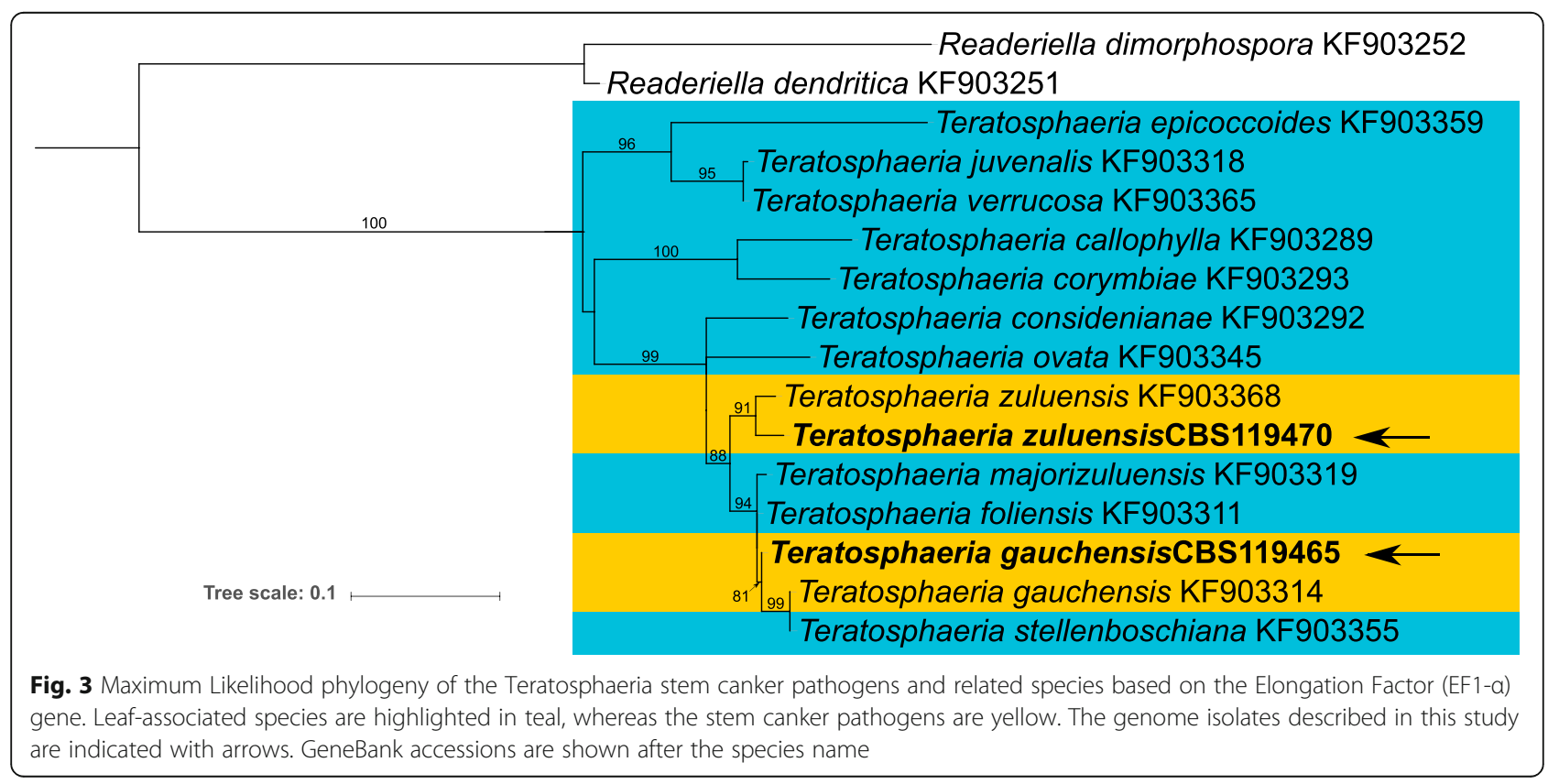




\section{Sequenced strain}

Teratosphaeria gauchensis: Uruguay: La Juanita: isol. Stem cankers on Eucalyptus grandis, Feb. 2005, M.J. Wingfield (CBS 119465 = CMW 50181- culture, PREM 62331 - dried culture).

Teratosphaeria zuluensis: South Africa: KwaZulu-Natal Province (Kwambonambi plantation): isol. Stem cankers on Eucalyptus grandis, Feb. 2005, M.J. Wingfield (CBS 119470 = CMW 50183 - culture, PREM 62332 - dried culture).

\section{Nucleotide accession number}

The genomic sequence data of $T$. gauchensis and $T$. zuluensis have been deposited at DDJ/EMBL/GenBank under the accessions VCMR00000000 (T. gauchensis) and VCMQ00000000 (T. zuluensis). This paper describes the first versions of these genomes.

\section{Material and methods}

Fungi were cultured on 2\% Malt Extract Agar (Merck, Wadeville, South Africa) at $25{ }^{\circ} \mathrm{C}$ for approximately 2 weeks. DNA was extracted as described for $T$. destructans (Wingfield et al. 2018b). The quality of the extracted DNA was estimated from the absorbance curve and the $260 / 280$ and $260 / 230$ absorbance ratios determined by a NanoDrop ND-1000 spectrophotometer (ThermoFisher Scientific, Wilmington, USA). DNA concentrations were determined with a Qubit ${ }^{\odot}$ 2.0 Fluorometer (Invitrogen, Carlsbad, California).

Teratosphaeria gauchensis (CBS 119465) was sequenced at Macrogen (Seoul, Korea) using a single PacBio Sequel SMRT Cell as well as a portion of an Illumina HiSeq 2500 lane at Inqaba Biotec (Pretoria, South Africa). The single paired-end Illumina library had an insert size of $550 \mathrm{bp}$ and a target read length of $250 \mathrm{bp}$. A hybrid assembly was computed by trimming the raw Illumina sequence reads with Trimmomatic 0.38 (Bolger et al. 2014) and using these in LoRDEC 0.6 (Salmela and Rivals 2014) to correct the PacBio reads. The corrected PacBio reads were assembled with Canu 1.7.1 (Koren et al. 2017). An Illumina assembly was subsequently constructed in SPAdes 3.10.1 (Bankevich et al. 2012), using k-mer values of 21, 33, 55, and 77 and applying the Canu assembly as "trusted reads". A final error correction of the hybrid assembly was performed with Pilon 1.22 (Walker et al. 2014).

Teratosphaeria zuluensis (CBS 119470) was sequenced with the Ion $520^{\mathrm{Ts}}$ \& Ion $530^{\mathrm{TM}}$ ExT Kit and an Ion $530^{\mathrm{TM}}$ Chip (ThermoFisher Scientific, MA) at the Central Analytical Facility (CAF, Stellenbosch University, South Africa). Assembly of reads was done with SPAdes 3.10.1 (Bankevich et al. 2012) using k-mer values 21, 33, 55, 77, 99, and 127. For both T. gauchensis and T. zuluensis, genome completeness was estimated with Benchmarking
Universal Single-Copy Orthologs (BUSCO) 2.0.1 (Simão et al. 2015) using the "Ascomycota odb9" dataset.

Repeats within each genome were identified with RepeatScout and masked with RepeatMasker Open-4.0.7 (http://www.repeatmasker.org). Annotation was performed with the MAKER 2.31.10 pipeline (Campbell et al. 2014) using pre-trained de novo gene predictors AUGUSTUS 3.3 (Stanke et al. 2006), GeneMark-ES Suite 4.35 (http://exon. gatech.edu/GeneMark/) and SNAP 2006-07-28 (Korf 2004). External EST and protein evidence from 15 other Capnodiales species were included in the annotation pipeline.

The Elongation Factor genes (EF1- $\alpha$ ) of the two stem canker pathogens were extracted from their genomes and used along with the EF1- $\alpha$ genes of related species (Quaedvlieg et al. 2014) for phylogenetic analysis. The Maximum Likelihood tree was computed with the PhyML+SMS "one-click" method on NGPhylogeny.fr (Lemoine et al. 2019). This protocol employs MAFFT (Katoh et al. 2017) for multiple alignment, BMGE (Criscuolo and Gribaldo 2010) for alignment curation and the aLRT SH-like method (Anisimova and Gascuel 2006) for calculating bootstrap support.

\section{Results and discussion}

Teratosphaeria gauchensis was assembled into 53 contigs larger than $1 \mathrm{~kb}$, with an $\mathrm{N} 50=1.44 \mathrm{Mb}$ and $\mathrm{L} 50=8$. This equated to a total assembly size of $30.27 \mathrm{Mb}$ with a GC content of $45.6 \%$. The PacBio reads provided an estimated genome coverage of $124 x$ with an additional $160 x$ coverage obtained from the Illumina data. The $T$. zuluensis assembly yielded 86 contigs above $1 \mathrm{~kb}$ (N50 = $1.00 \mathrm{Mb}, \mathrm{L} 50=12$ ), an estimated genome size of 28.71 $\mathrm{Mb}, 44.5 \% \mathrm{GC}$ and estimated $155 \mathrm{x}$ genome coverage. The search for 1315 Ascomycota ortholog proteins identified 97.6\% (1285) single-copy orthologs in T. gauchensis and 96.9\% (1274) in T. zuluensis, indicating that these genomes are ca. 97\% complete. This presents a higher level of completeness than the $84.5 \%$ of $T$. destructans, the only other published Teratosphaeria genome (Wingfield et al. 2018b).

A similar number of genes were predicted in T. gauchensis and T. zuluensis at 11699 and 11520, respectively. Of these, 9304 predictions in T. gauchensis and 9457 in T. zuluensis were supported by external evidence. Both genomes had a low repeat content of $2.2 \%$, much lower than the ca.17\% estimated for $T$. destructans (GenBank RIBY01000000). Since the genomes of these stem canker pathogen species, as well as $T$. destructans, were sequenced with long-read technologies, we are confident that this is not an underestimate, but reflects the true repeat content in these genomes.

The EF1- $\alpha$ gene tree (Fig. 3) illustrates the relationship of T. zuluensis and T. gauchensis to leaf-associated Teratosphaeria species. This phylogeny, as well as others 
(Aylward et al. 2019; Quaedvlieg et al. 2014), suggests that the association with Eucalyptus stem cankers evolved more than once. The T. zuluensis genome isolate CBS119470 groups with the ex-epitype strain CBS120301 (KF903368), however, the T. gauchensis strain sequenced in this study (CBS119465) groups sister to a clade that contains an ex-type strain (CBS120304; KF903314) of $T$. gauchensis and T. stellenboschiana. A similar phylogenetic relationship is apparent with both the ITS and $\beta$-tubulin gene regions as well as with concatenated gene trees (data not shown). Teratosphaeria gauchensis is known to represent a species complex displaying statistical support for subgroups within the species (Aylward et al. 2019; Silva et al. 2015). Future studies should take the taxonomic position of this genome isolate into consideration when interpreting genomic data.

Several other fungal groups affect Eucalyptus stems, including species in the genera Chrysoporthe (Gryzenhout et al. 2004), Cytospora (Adams et al. 2006), Holocryphia (Van der Westhuizen et al. 1993) and Neofusicoccum (Slippers et al. 2009). Of these, genomes of Eucalyptus-specific isolates are available only for Chrysoporthe austroafricana, C. cubensis and $C$. deuterocubensis, the causal agents of Cryphonectria canker (Wingfield et al. 2015a, 2015b). Teratosphaeria gauchensis and T. zuluensis, therefore, represent the second group of Eucalyptus stem canker pathogens to be sequenced. In future, comparative genomics projects that include various Eucalyptus stem pathogens as well as closely related species associated with other plant organs (e.g. T. destructans), may reveal fungal characteristics that enable stem pathogenicity.

Authors: J. Aylward, B.D. Wingfield, L.L. Dreyer, F. Roets, C.J. van Heerden, M.J. Wingfield.

Contact: Janneke.Aylward@fabi.up.ac.za

\section{Abbreviations}

aLRT SH: Aproximate Likelihood Ratio Test for branches; ANNIE: ANNotation Information Extractor; AUGUSTUS: Software for gene prediction; BLAST: Basic Local Alignment Search Tool; BLASTp: Basic Local Alignment Search Tool for protein sequences; BMGE: Block Mapping and Gathering with Entropy; BUSCO: Benchmarking Universal Single-Copy Orthologs; Canu: A hierarchical assemblypipeline; cDNA: Complementary Deoxyribose Nucleic Acid; CWD: Coffee wilt disease; DDBJ: DNA Data Bank of Japan; DNA: Deoxyribose Nucleic Acid; DST: Department of Science and Technology of South Africa; EF1-a: Elongation Factor 1 alpha gene; EMBL: Nucleotide Sequence Data Library; ENA: European Nucleotide Archive; FABl: Forestry and Agricultural Biotechnology Institute; FFSC: F. fujikuroi species complex; GenBank: NIH genetic sequence database; GeneMark: Gene prediction software; ITS Internal: Transcribed Spacer; LoRDEC: Hybrid error correction program; MAFFT: Multiple Alignment using Fast Fourier Transform; MEGA: Molecular Evolutionary Genetics Analysis; NCBI: National Center for Biotechnology Information; NRF: National Research Foundation (NRF); ORF(s): Open reading frame(s); PhyML: Phylogeny software based on maximum-likelihood principle; PREM: South African National Collection of Fungi; RNA: Ribose Nucleic Acid; rRNA: Ribosomal Ribo Nucleic Acid; SARChl: South African Research Chairs Initiative; SMS: Smart Model Selection in PhyML; SNAP: Web-based tool for identification and annotation of proxy Single Nucleotide Polymorphisms; SPAdes: St. Petersburg genome assembler; SSPACE: SSAKE-based Scaffolding of Pre-Assembled Contigs after Extension program; tRNA: Ribo Nucleic Acid; USA: United States of America

\section{Acknowledgements}

For the Ceratocystis annotation project Alisa Postma-Smidt is acknowledged for providing assistance with the genome assembly and read mapping. Dr. Fourie Joubert and Alisa Postma-Smidt also provided assistance with genome annotation and curation. We acknowledge a team of students and staff members in FABI that assisted in the genome jamboree for manual curation of the gene models: Tayo Adenigba, Dr. Dave Berger, Wilma Janine, Claire Jordaan, Kayleigh Maier, Mandy Messal, Ramesh Moolam, Lizel Potgieter, Catherine Tatham, Conrad Trollip, Salome van Hoepen, Bradley Vincent, Dr. Markus Wilken and Andi Wilson.

\section{Adherence to national and international regulations}

Not applicable to the specific isolates used in this manuscript. All isolates are maintained in culture collections as per government regulations and quarentine specifications.

\section{Authors' contributions}

The manuscript is comprised of three sections, 11A, 11B, 11C. Each are authored separately and there is a specific contact person. In each case the contact person has taken the lead in writing and compiling the manuscuript. The other authors have been involved in the idea behind the manuscript, editing and analysis of the data. All authors read and approved the final manuscript.

11A Genome annotation for Ceratocystis fimbriata: an aggressive fungal pathogen of root crops

Authors: A. Fourie*, M.C. Simpson*, T.A. Duong, I. Barnes, M.P..A. Coetzee, M.A. van der Nest, M.J. Wingfield and B.D. Wingfield

Contact: melissa.simpson@fabi.up.ac.za or arista.fourie@fabi.up.ac.za

(*authors contributed equally)

11B Draft genome sequence of Fusarium xylarioides

Authors: V.S. Bushula-Njah, T.A. Duong, D.M. Geiser, E.T. Steenkamp, and B.D. Wingfield

Contact: Vuyiswa.bushula@fabi.up.ac.za

11C Draft genome sequences of Teratosphaeria gauchensis and T. zuluensis, causal agents of Teratosphaeria stem canker

Authors: J. Aylward, B.D. Wingfield, L.L. Dreyer, F. Roets, C.J. van Heerden, M.J. Wingfield

Contact: Janneke.Aylward@fabi.up.ac.za

\section{Authors' information}

No additional information provided.

\section{Funding}

We acknowledge the National Research Foundation (NRF) and Department of Science and Technology (DST) of South Africa for providing scholarship funding for students as well as members of the Tree Protection Cooperative Programme at the Forestry and Agricultural Biotechnology Institute for providing financial support for this project. These projects from part of the DST/NRF Centre of Excellence in Tree Health Biotechnology and the SARChl in Fungal Genomics.

\section{Availability of data and materials}

All data and material is available the relevant details (data banks, culture collections and herbaria) are given in the manuscript.

Ethics approval and consent to participate

Not applicable, no humans, human subjects nor data were used in this manuscript.

\section{Consent for publication}

Not applicable.

\section{Competing interests}

The authors declare that they have no competing interests.

\section{Author details}

'Department of Biochemistry, Genetics and Microbiology (BGM), Forestry and Agricultural Biotechnology Institute (FABI), University of Pretoria, Private Bag X20, Hatfield 0028, South Africa. ${ }^{2}$ Department of Botany and Zoology, Stellenbosch University, Private Bag X1, Matieland 7602, South Africa.

${ }^{3}$ Fusarium Research Center, Department of Plant Pathology and 
Environmental Microbiology, 121 Buckhout Lab, University Park, State College, PA 16802, USA. ${ }^{4}$ Department of Conservation Ecology and Entomology, Stellenbosch University, Private Bag X1, Matieland 7602, South Africa. ${ }^{5}$ Central Analytical Facilities, Stellenbosch University, Private Bag X1, Matieland 7602, South Africa. ${ }^{6}$ Biotechnology Platform, Agricultural Research Council, Private Bag X05, Onderstepoort 0002, South Africa.

Received: 8 June 2019 Accepted: 1 July 2019

Published online: 13 September 2019

\section{References}

Adams G, Roux J, Wingfield M (2006) Cytospora species (Ascomycota, Diaporthales, Valsaceae): introduced and native pathogens of trees in South Africa. Australas Plant Pathol 35:521-548

Andrews S (2010) FastQC: a quality control tool for high throughput sequence data. http://www.bioinformatics.babraham.ac.uk/projects/fastqc

Anisimova M, Gascuel O (2006) Approximate likelihood-ratio test for branches: a fast, accurate, and powerful alternative. Syst Biol 55:539-552

Aylward J, Roets F, Dreyer LL, Wingfield MJ (2019) Teratosphaeria stem canker of Eucalyptus: two pathogens, one devastating disease. Mol Plant Pathol 20:8-19

Baker CJ, Harrington TC, Krauss U, Alfenas AC (2003) Genetic variability and host specialization in the Latin American clade of Ceratocystis fimbriata. Phytopathology 93:1274-1284

Bankevich A, Nurk S, Antipov D, Gurevich AA, Dvorkin M, Kulikov AS et al (2012) SPAdes: a new genome assembly algorithm and its applications to single-cell sequencing. J Comput Biol 19:455-477

Barnes I, Fourie A, Wingfield M, Harrington T, McNew D et al (2018) New Ceratocystis species associated with rapid death of Metrosideros polymorpha in Hawai'i. Persoonia Mol Phylogeny Evol Fungi 40:154-181

Beukes CW, Venter SN, Law IJ, Phalane FL, Steenkamp ET (2013) South African papilionoid legumes are nodulated by diverse Burkholderia with unique nodulation and nitrogen-fixation loci. PLoS One 8:e68406

Boetzer M, Henkel CV, Jansen HJ, Butler D, Pirovano W (2011) Scaffolding preassembled contigs using SSPACE. Bioinformatics 27:578-579

Boetzer M, Pirovano W (2012) Toward almost closed genomes with GapFiller. Genome Biol 13:R56

Bolger AM, Lohse M, Usadel B (2014) Trimmomatic: a flexible trimmer for Illumina sequence data. Bioinformatics 30:2114-2120

Campbell MS, Holt C, Moore B, Yandell M (2014) Genome annotation and curation using MAKER and MAKER-P. Curr Protoc Bioinformatics 48:4.11. 11-14.11. 39

Cantarel BL, Korf I, Robb SMC, Parra G, Ross E et al (2008) MAKER: an easy-to-use annotation pipeline designed for emerging model organism genomes. Genome Res 18:188-196

Cortinas MN, Crous PW, Wingfield BD, Wingfield MJ (2006) Multi-gene phylogenies and phenotypic characters distinguish two species within the Colletogloeopsis zuluensis complex associated with Eucalyptus stem cankers. Stud Mycol 55:133-146

Criscuolo A, Gribaldo S (2010) BMGE (block mapping and gathering with entropy): a new software for selection of phylogenetic informative regions from multiple sequence alignments. BMC Evol Biol 10:210

De Beer ZW, Duong TA, Barnes I, Wingfield BD, Wingfield MJ (2014) Redefining Ceratocystis and allied genera. Stud Mycol 79:187-219

De Wit PJGM, Van Der Burgt A, Ökmen B, Stergiopoulos I, Abd-Elsalam KA et al (2012) The genomes of the fungal plant pathogens Cladosporium fulvum and Dothistroma septosporum reveal adaptation to different hosts and lifestyles but also signatures of common ancestry. PLoS Genet 8:e1003088

DeLong EF (1992) Archaea in coastal marine environments. Proc Natl Acad Sci 89:5685-5689

Dobin A, Davis CA, Schlesinger F, Drenkow J, Zaleski C et al (2013) STAR: ultrafast universal RNA-seq aligner. Bioinformatics 29:15-21

Duong TA, De Beer ZW, Wingfield BD, Wingfield MJ (2013) Characterization of the mating-type genes in Leptographium procerum and Leptographium profanum. Fungal Biology 117:411-421

Fourie A, Wingfield MJ, Wingfield BD, Barnes I (2015) Molecular markers delimit cryptic species in Ceratocystis sensu stricto. Mycol Prog 14:1020

Fourie A, Wingfield MJ, Wingfield BD, van der Nest MA, Loots MT et al (2018) Inheritance of phenotypic traits in the progeny of a Ceratocystis interspecific cross. Fungal Biology 122:717-729
Geiser DM, Lewis-Ivey ML, Hakiza G, Juba JH, Miller SA (2005) Gibberella xylarioides (anamorph: Fusarium xylarioides), a causative agent of coffee wilt disease in Africa, is a previously unrecognized member of the G. fujikuroi species complex. Mycologia 97:191-201

Goodwin SB, Drenth A, Fry WE (1992) Cloning and genetic analyses of two highly polymorphic, moderately repetitive nuclear DNAs from Phytophthora infestans. Curr Genet 22:107-115

Gryzenhout M, Myburg H, Van der Merwe NA, Wingfield BD, Wingfield MJ (2004) Chrysoporthe, a new genus to accommodate Cryphonectria cubensis. Stud Mycol 50:119-142

Hall B, DeRego T, Geib S (2014) GAG: the genome annotation generator. (Version 1.0) [Software]. Available from http://genomeannotation.github.io/GAG

Halsted BD (1890) Some fungous disease of the sweet potato. Agric College Exp Station Bull 76:1-32

Halsted BD, Fairchild DG (1891) Sweet-potato black rot. J Mycol 7:1-11

Harrington TC, MCNew DL (1997) Self-fertility and uni-directional matingtype switching in Ceratocystis coerulescens, a filamentous ascomycete. Curr Genet 32:52-59

Heim R (1950) La carbunculariose du Caféier. Suppl Colon a la Revue de Mycol 15:89-98

Hoff KI, Lange S, Lomsadze A, Borodovsky M, Stanke M (2016) BRAKER1: unsupervised RNA-Seq-based genome annotation with GeneMark-ET and AUGUSTUS. Bioinformatics 32:767-769

Holland, LA, DP Lawrence, MT Nouri, R Travadon, TC Harrington, FP Trouillas, (2019) Taxonomic Revision and Multi-locus Phylogeny of theNorth American Clade of Ceratocystis. Fungal Systematics and Evolution 3 (1):135-156.

Holt C, Yandell M (2011) MAKER2: an annotation pipeline and genome-database management tool for second-generation genome projects. BMC Bioinformatics 12:491

Jimu L, Wingfield MJ, Mwenje E, Roux J (2014) First report of Teratosphaeria zuluensis causing stem canker of Eucalyptus grandis in Uganda. For Pathol 44:242-245

Jimu L, Wingfield MJ, Mwenje E, Roux J (2015) Diseases on Eucalyptus species in Zimbabwean plantations and woodlots. South Forests 77:221-230

Jones P, Binns D, Chang H-Y, Fraser M, Li W et al (2014) InterProScan 5: genomescale protein function classification. Bioinformatics 30:1236-1240

Käll L, Krogh A, Sonnhammer ELL (2004) A combined transmembrane topology and signal peptide prediction method. J Mol Biol 338:1027-1036

Katoh K, Rozewicki J, Yamada KD (2017) MAFFT online service: multiple sequence alignment, interactive sequence choice and visualization. Brief Bioinform. https:/ doi.org/10.1093/bib/bbx108.

Katoh K, Standley DM (2013) MAFFT multiple sequence alignment software version 7: improvements in performance and usability. Mol Biol Evol 30:772-780

King R, Urban M, Hammond-Kosack MCU, Hassani-Pak K, Hammond-Kosack KE (2015) The completed genome sequence of the pathogenic ascomycete fungus Fusarium graminearum. BMC Genomics 16:544

Klosterman SJ, Subbarao KV, Kang S, Veronese P, Gold SE et al (2011) Comparative genomics yields insights into niche adaptation of plant vascular wilt pathogens. PLoS Pathog 7:e1002137

Koren S, Walenz BP, Berlin K, Miller JR, Bergman NH, Phillippy AM (2017) Canu: scalable and accurate long-read assembly via adaptive $k$-mer weighting and repeat separation. Genome Res 27:722-736

Korf I (2004) Gene finding in novel genomes. BMC Bioinformatics 5:59

Kumar S, Stecher G, Li M, Knyaz C, Tamura K (2018) MEGA X: molecular evolutionary genetics analysis across computing platforms. Mol Biol Evol 35:1547-1549

Kumar S, Stecher G, Tamura K (2016) MEGA7: molecular evolutionary genetics analysis version 7.0 for bigger datasets. Mol Biol Evol 33:1870-1874

Lee E, Helt GA, Reese JT, Munoz-Torres MC, Childers CP et al (2013) Web Apollo: a web-based genomic annotation editing platform. Genome Biol 14:R93

Lemoine F, Correia D, Lefort V, Doppelt-Azeroual O, Mareuil F, Cohen-Boulakia S et al (2019) NGPhylogeny. Fr: new generation phylogenetic services for nonspecialists. Nucleic Acids Res 47(W1):W260-W265

Lepoint PCE, Munaut FTJ, Maraite HMM (2005) Gibberella xylarioides Sensu Lato from Coffea canephora: a new mating population in the Gibberella fujikuroi species complex. Appl Environ Microbiol 71:8466-8471

Lewthwaite SL, Wright PJ, Triggs CM (2011) Sweetpotato cultivar susceptibility to infection by Ceratocystis fimbriata. New Zealand Plant Prot 64:1-6

Li Q, Harrington TC, McNew D, Li J, Huang Q et al (2016) Genetic bottlenecks for two populations of Ceratocystis fimbriata on sweet potato and pomegranate in China. Plant Dis 100:2266-2274 
Liu F, Barnes I, Roux J, Wingfield MJ, Chen S (2018) Molecular phylogenetics and microsatellite analysis reveal a new pathogenic Ceratocystis species in the Asian-Australian clade. Plant Pathol 67:1097-1113

Lomsadze A, Burns PD, Borodovsky M (2014) Integration of mapped RNA-Seq reads into automatic training of eukaryotic gene finding algorithm. Nucleic Acids Res 42:e119

Marin-Felix Y, Groenewald JZ, Cai L, Chen Q, Marincowitz S et al (2017) Genera of phytopathogenic fungi: GOPHY 1. Stud Mycol 86:99-216

Molano EPL, Cabrera OG, Jose J, do Nascimento LC, Carazzolle MF et al (2018) Ceratocystis cacaofunesta genome analysis reveals a large expansion of extracellular phosphatidylinositol-specific phospholipase-C genes (PI-PLC) BMC Genomics 19:58-58

O'Donnell K, Cigelnik E, Nirenberg HI (1998) Molecular systematics and phylogeography of the Gibberella fujikuroi species complex. Mycologia 90:465-493

O'Donnell K, Nirenberg HI, Aoki T, Cigelnik E (2000) A multigene phylogeny of the Gibberella fujikuroi species complex: detection of additional phylogenetically distinct species. Mycoscience 41:61-78

Old KM, Wingfield MJ, Yuan ZQ (2003) A manual of diseases of eucalypts in South-East Asia. CIFOR, Jakarta

Ooi HS, Kwo CY, Wildpaner M, Sirota FL, Eisenhaber B et al (2009) ANNIE: integrated de novo protein sequence annotation. Nucleic Acids Res 37:W435-W440

Petersen TN, Brunak S, von Heijne G, Nielsen H (2011) SignalP 4.0: discriminating signal peptides from transmembrane regions. Nat Methods 8:785

Ploetz RC (2006) Fusarium-induced diseases of tropical, perennial crops. Phytopathology 96:648-652

Price AL, Jones NC, Pevzner PA (2005) De novo identification of repeat families in large genomes. Bioinformatics 21:i351-i358

Quaedvlieg W, Binder M, Groenewald JZ, Summerell BA, Carnegie AJ, Burgess TI et al (2014) Introducing the consolidated species concept to resolve species in the Teratosphaeriaceae. Persoonia 33:1-40

Rutherford MA (2006) Current knowledge of coffee wilt disease, a major constraint to coffee production in Africa. Phytopathology 96:663-666

Salmela L, Rivals E (2014) LoRDEC: accurate and efficient long read error correction. Bioinformatics 30:3506-3514

Scruggs AC, Basaiah T, Adams ML, Quesada-Ocampo LM (2017) Genetic diversity, fungicide sensitivity, and host resistance to Ceratocystis fimbriata infecting Sweetpotato in North Carolina. Plant Dis 101:994-1001

Silva MRC, Diogo E, Bragança H, Machado H, Phillips AJL (2015) Teratosphaeria gauchensis associated with trunk, stem and foliar lesions of Eucalyptus globulus in Portugal. For Pathol 45:224-234

Simão FA, Waterhouse RM, loannidis P, Kriventseva EV, Zdobnov EM (2015) BUSCO: assessing genome assembly and annotation completeness with single-copy orthologs. Bioinformatics 31:3210-3212

Slippers B, Burgess T, Pavlic D, Ahumada R, Maleme H, Mohali S et al (2009) A diverse assemblage of Botryosphaeriaceae infect Eucalyptus in native and non-native environments. South Forests 71:101-110

Smit AFA, Hubley R, Green P (1996-2010) RepeatMasker Open-3.0. http:// WWW.repeatmasker.org

Solovyev V, Kosarev P, Seledsov I, Vorobyev D (2006) Automatic annotation of eukaryotic genes, pseudogenes and promoters. Genome Biol 7:1-12

Stamatakis A (2014) RAxML version 8: a tool for phylogenetic analysis and postanalysis of large phylogenies. Bioinformatics 30:1312-1313

Stanke M, Keller O, Gunduz I, Hayes A, Waack S, Morgenstern B (2006) AUGUSTUS: ab initio prediction of alternative transcripts. Nucleic Acids Res 34:W435-W439

Stanke M, Steinkamp R, Waack S, Morgenstern B (2004) AUGUSTUS: a web server for gene finding in eukaryotes. Nucleic Acids Res 32:W309-W312

Steyaert RL (1948) Contribution al'étude des parasites des végétaux du Congo Belge. R Bot Soc Belgium Ser 2 30:11-58

Trapnell C, Roberts A, Goff L, Pertea G, Kim D et al (2012) Differential gene and transcript expression analysis of RNA-seq experiments with TopHat and cufflinks. Nat Protoc 7:562-578

Van der Nest MA, Beirn LA, Crouch JA, Demers JE, de Beer ZW et al (2014a) Draft genomes of Amanita jacksonii,Ceratocystis albifundus, Fusarium circinatum, Huntiella omanensis, Leptographium procerum, Rutstroemia sydowiana, and Sclerotinia echinophila. IMA Fungus 5:472-485

Van der Nest MA, Bihon W, de Vos L, Naidoo K, Roodt D et al (2014b) Draft genome sequences of Diplodia sapinea, Ceratocystis manginecans, and Ceratocystis moniliformis. IMA Fungus 5:135-140

Van der Nest MA, Steenkamp ET, McTaggart AR, Trollip C, Godlonton T et al (2015) Saprophytic and pathogenic fungi in the Ceratocystidaceae differ in their ability to metabolize plant-derived sucrose. BMC Evol Biol 15:273
Van der Westhuizen I, Wingfield M, Kemp G, Swart W (1993) First report of the canke pathogen Endothia gyrosa on Eucalyptus in South Africa. Plant Pathol 42:661-663

Vanderpool D, Bracewell RR, McCutcheon JP (2018) Know your farmer: ancient origins and multiple independent domestications of ambrosia beetle fungal cultivars. Mol Ecol 27:2077-2094

Walker BJ, Abeel T, Shea T, Priest M, Abouelliel A, Sakthikumar S et al (2014) Pilon: an integrated tool for comprehensive microbial variant detection and genome assembly improvement. PLoS One 9:e112963

Weber T, Blin K, Duddela S, Krug D, Kim HUK et al (2015) antiSMASH 3.0-a comprehensive resource for the genome mining of biosynthetic gene clusters. Nucleic Acids Res 43:W237-W243

White TJ, Bruns T, Lee S, Taylor J (1990) Amplification and direct sequencing of fungal ribosomal RNA genes for phylogenetics. In: Innis MA, Gelfand DH, Sninsky JJ, White TJ (eds) PCR protocols: a sequencing guide to methods and applications. Academic Press Inc., San Diego, pp 315-322

Wilken PM, Steenkamp ET, Wingfield MJ, De Beer ZW, Wingfield BD (2013) Draft nuclear genome sequence for the plant pathogen, Ceratocystis fimbriata. IMA Fungus 4:357-358

Wilken PM, Steenkamp ET, Wingfield MJ, De Beer ZW, Wingfield BD (2014) DNA loss at the Ceratocystis fimbriata mating locus results in self-sterility. PLoS One 9:e92180

Wingfield BD, Ades PK, Al-Naemi FA, Beirn LA, Bihon W et al (2015a) Draft genome sequences of Chrysoporthe austroafricana, Diplodia scrobiculata, Fusarium nygamai, Leptographium lundbergii, Limonomyces culmigenus, Stagonosporopsis tanaceti, and Thielaviopsis punctulata. IMA Fungus 6:233-248

Wingfield BD, Ambler JM, Coetzee M, De Beer ZW, Duong TA et al (2016a) Draft genome sequences of Armillaria fuscipes, Ceratocystiopsis minuta, Ceratocystis adiposa, Endoconidiophora laricicola, E. polonica and Penicillium freii DAOMC 242723. IMA Fungus 7:217-227

Wingfield BD, Barnes I, de Beer ZW, De Vos L, Duong TA et al (2015b) Draft genome sequences of Ceratocystis eucalypticola, Chrysoporthe cubensis, C. deuterocubensis, Davidsoniella virescens, Fusarium temperatum, Graphilbum fragrans, Penicillium nordicum, and Thielaviopsis musarum. IMA Fungus 6:493-506

Wingfield BD, Berger DK, Steenkamp ET, Lim H-J, Duong TA et al (2017) Draft genome of Cercospora zeina, Fusarium pininemorale, Hawksworthiomyces lignivorus, Huntiella decipiens and Ophiostoma ips. IMA Fungus 8:385-396

Wingfield BD, Bills GF, Dong Y, Huang W, Nel WJ et al (2018a) Draft genome sequence of Annulohypoxylon stygium, Aspergillus mulundensis, Berkeleyomyces basicola (syn. Thielaviopsis basicola), Ceratocystis smalleyi, two Cercospora beticola strains, Coleophoma cylindrospora, Fusarium fracticaudum, Phialophora cf. hyalina, and Morchella septimelata. IMA Fungus 9:199-223

Wingfield BD, Duong TA, Hammerbacher A, Van der Nest MA, Wilson A et al (2016b) Draft genome sequences for Ceratocystis fagacearum, C. harringtonii, Grosmannia penicillata, and Huntiella bhutanensis. IMA Fungus 7:317-323

Wingfield BD, Liu M, Nguyen HDT, Lane FA, Morgan SW et al (2018b) Nine draft genome sequences of Claviceps purpurea s.lat., including C. arundinis, C. humidiphila, and C. cf. spartinae, pseudomolecules for the pitch canker pathogen Fusarium circinatum, draft genome of Davidsoniella eucalypti, Grosmannia galeiformis, Quambalaria eucalypti, and Teratosphaeria destructans. IMA Fungus 9:401-418

Wingfield MJ, Barnes I, De Beer ZW, Roux J, Wingfield BD et al (2017b) Novel associations between ophiostomatoid fungi, insects and tree hosts: current status - future prospects. Biol Invasions 19:3201-3214

Wingfield MJ, Crous PW, Coutinho TA (1996) A serious canker disease of Eucalyptus in South Africa caused by a new species of Coniothyrium. Mycopathologia 136:139-145

Witthuhn RC, Harrington TC, Wingfield BD, Steimel JP, Wingfield MJ (2000) Deletion of the MAT-2 mating-type gene during uni-directional mating-type switching in Ceratocystis. Curr Genet 38:48-52

Zerbino DR, Birney E (2008) Velvet: algorithms for de novo short read assembly using de Bruijn graphs. Genome Res 18:821-829

\section{Publisher's Note}

Springer Nature remains neutral with regard to jurisdictional claims in published maps and institutional affiliations. 